\title{
Occurrence of Kurzia polyspina Hudec (Crustacea, Anomopoda, Chydoridae) in Brazil
}

\author{
Lourdes M. A. Elmoor-Loureiro $^{1}$
}

\begin{abstract}
The cladoceran Kurzia polyspina Hudec, 2000 (Anomopoda, Chydoridae) was found associated with Eichhornia Kunth, 1843 (Pontederiaceae) roots in Paranoá Lake, Brasília. It represents the first record of this species in Brazil and in the Southern Hemisphere. Comments on Kurzia Dybowski \& Grochowski, 1894 South American records are included.

KEY WORDS. Anomopoda, Chydoridae, Kurzia polyspina, first record
\end{abstract}

For a long time, Kurzia latissima (Kurz, 1874) (Anomopoda, Chydoridae) was considered a cosmopolitan species (SMIRNOV 1974). Lately, however, HUDEC (2000) has shown that New World's populations formerly considered K. latissima belonged to a different species. For the Neotropics, he proposed a new species Kurzia polyspina Hudec, 2000, which has been found in Mexico, Cuba and Surinam.

Reporting the occurrence of $K$. polyspina in Paranoá Lake (Brasília, central Brazil), the present study represents the first record of this species in the Southern Hemisphere.

The sample was taken from the littoral zone of Paranoá lake, in April $3^{\text {th }}$ 1987. Some Eichhornia Kunth, 1843 (Pontederiaceae) individuals were shaken into a recipient filled with reservoir water, which was then passed through a plankton net. The sample was preserved in formalin $4 \%$.

The only three $K$. polyspina individuals found in the sample are females. They are mounted in glycerin jelly and one of them deposited at Museu Nacional, Rio de Janeiro (MNRJ 15446).

The individuals match the diagnostic characters presented by HUDEC (2000): Subretangular body (Fig. 1), antennules almost reaching rostral tip (Figs 1 and 2), antenna with basal segment seta delicate and short (Fig. 7), three main head pores (Fig. $3)$, labrum subtriangular in shape with anterior margin slightly curved and undulate (Fig. 4), postero-ventral and posterior carapace margin with identical setulae (Fig. 5), postabdomen (Fig. 6) with distal corner angular and with one cluster of spicula-like marginal denticles, 8-9 clusters of spicule-like denticles on postanal margin, terminal claw with a non-serrated basal denticle twice as long as basal width of terminal claw, the two longer setae (Fig. 8) on inner distal lobe (IDL) of the first trunk limb different serrated (two different spicules and setules).

According to SMIRNOv (1974), two Kurzia Dybowski \& Grochowski, 1894 species were recorded in South America: Kurzia latissima (Kurz, 1874) and Kurzia longirostris Daday, 1898.

1) Laboratório de Zoologia, Universidade Católica de Brasília. QS 7 lote 1, Bloco M, sala 331 , 72030-170 Taguatinga, Distrito Federal, Brasil. E-mail: lourdes@ucb.br 


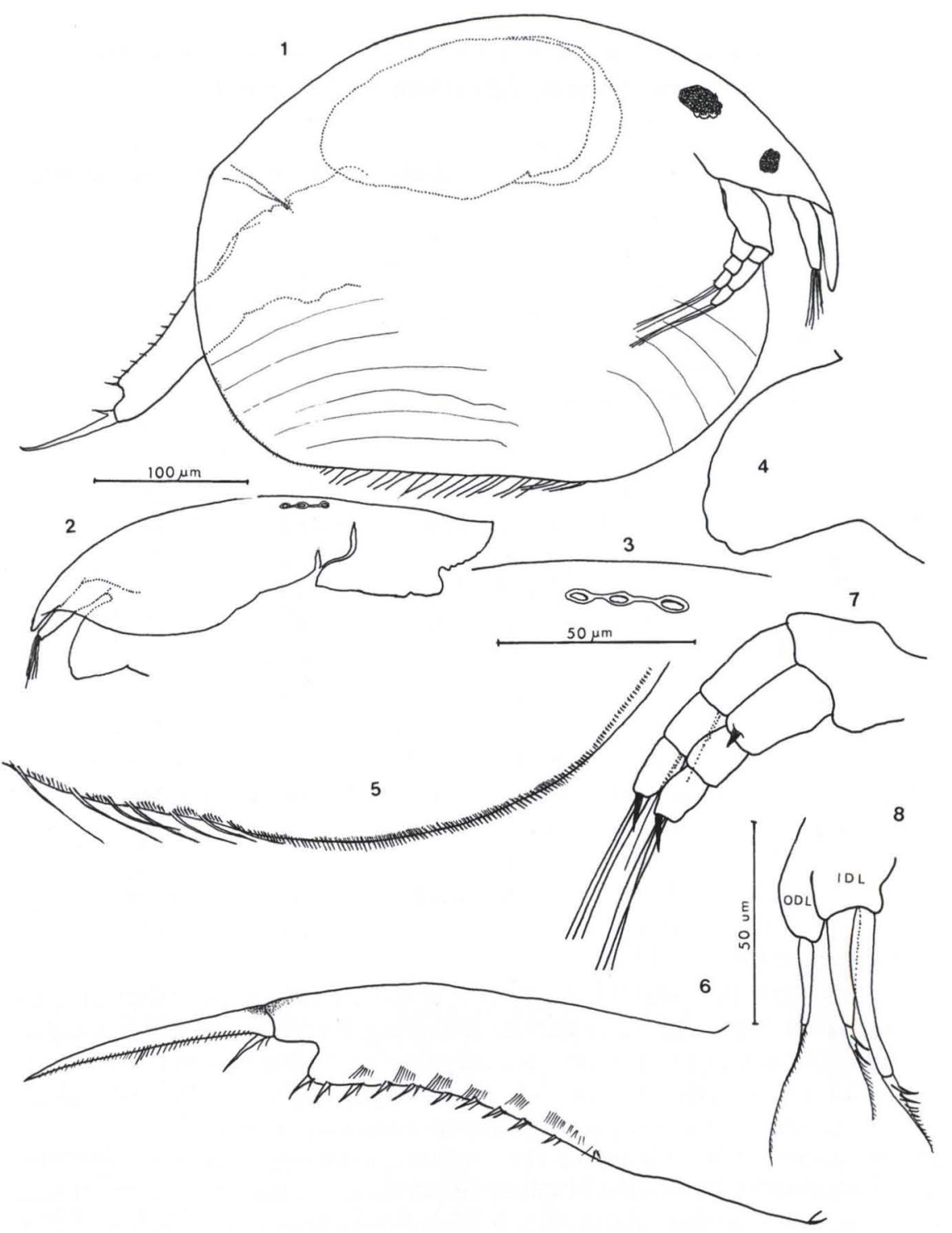

Fig. 1-8. Kurzia polyspina. (1) Adult female, lateral view; (2) head shield, lateral view, distorted to show the head pores; (3) head pores; (4) labrum; (5) postero-ventral and posterior margin of carapace.; (6) postabdomen; (7) antenna; (8) setae on outer (ODL) and inner distal lobe (IDL) of the trunk limb I.

Kurzia latissima and $K$. polyspina are very similar and to differentiate one from the other, the most important characters are the lateral serration of the two longest IDL setae (spicules and setules in $K$. polyspina; uniform setules in $K$. 
latissima) and the form of postabdominal distal corner and number of denticles at it (angular with 1 denticle in $K$. polyspina; blunt with 2-3 denticles in $K$. latissima).

The distributional pattern presented by HUDEC (2000) for K. latissima suggests the necessity of reassessment of the previous Brazilian (SARS 1901; MONTÚ \& GLOEDEN 1986) and other South American records (DADAY 1905; STINGELIN 1913; PAGGi 1995), which probably belong to K. polyspina. Indeed, HUDEC (2000) suggested that Kurzia cf. latissima recorded in Venezuela (REY \& VASQUEZ 1986) belongs to K. polyspina. The same could be suggested for Argentine populations attributed to $K$. latissima, whose postabdomen drawn by PAGGI (1995) shows $K$. polyspina characteristics.

Kurzia longirostris is easily differentiated from the two previously cited species by its long rostrum, triangular labrum, short basal spine, and posterior head pore transversely elongated (HUDEC 2000). It was described from Ceylon (Sri Lanka) and reported in South America only twice (SARS 1901; DADAY 1905). Despite being considered a pantropical species, it is possible that $K$. longirostris represents a species complex, as shyly suggested by HUDEC (2000) putting a question mark after the indication of its distribution. It is in accordance with several authors (e.g. DUMONT 1997) who advocated the necessity for revision of the so-called cosmopolitan species. Consequently, the South American records should be considered under suspicion.

ACKNOWLEDGMENTS. I thank Ms. Vania Danigno for revising the English version of this paper. This study was financially supported by the Pró-Reitoria de Pós-graduação e Pesquisa of the Universidade Católica de Brasília.

\section{REFERENCES}

Daday, E.V. 1905. Untersuchungen über die Süsswasser-Mikrofauna Paraguays. Zoologica 18 (44): 1-375.

Dumont, H.J. 1997. Cladoceran studies: where do we go from here? Hydrobiologia 360: 301-303.

HudEC, I. 2000. Subgeneric differentiation within Kurzia (Crustacea: Anomopoda: Chydoridae) and a new species from Central America. Hydrobiologia 421: 165-178.

Montú, M. \& I.M. Gloeden. 1986. Atlas dos Cladocera e Copepoda (Crustacea) do estuário da Lagoa dos Patos (Rio Grande, Brasil). Nerítica, Pontal do Paraná, 1 (2): 1-134.

PAGgi, J.C. 1995. Crustacea Cladocera, p. 909-951. In: E.C. Lopretto \& G. TElL (Eds). Ecossistema de Aguas Continentales: Metodologias para su estudio. 3. La Plata, Ediciones Sur, 1401p.

REY, J. \& E. VASQUEZ. 1986. Cladocères de quelques corps d'eaux douce du bassin moyen de l'Orenoque (Venezuela). Ann. Limnol. 22 (2): 137-168.

SARS, G.O. 1901. Contribution to the knowledge of the fresh-water Entomostraca of South America. Part I. Cladocera. Archiv Mathematik Naturvidenskab, Christiania, 23 (3): 1-102.

Smirnov, N.N. 1974. Chydoridae of the world's fauna. Fauna of the URSS, Crustacea 1 (2): 1-644. Stingelin, T. 1913. Cladoceren aus den Gebirgen von Kolumbien. Mem. Soc. Neuchateloise Sci. Nat. 5: 600-638.

Recebido em 10.VIII.2001; aceito em 18.II.2002. 